\title{
PEMIKIRAN FIQH AHMAD ZAHRO TENTANG ISTINBÂT MANHAJÎ SEBAGAI METODE PERUMUSAN HUKUM ISLAM
}

\author{
Siti Maryam Qurotul Aini \\ Sekolah Tinggi Agama Islam Darussalam Nganjuk, Indonesia \\ E-mail: sitimaryamqa@yahoo.co.id
}

\begin{abstract}
This article examines how Ahmad Zahro establishes the concept of practical use of istinbât manhajî in the establishment of Islamic law. In this case, although Zahro claims himself as a follower of a particular school in the field of fiqh, he chooses to use the manhajî method, because this method is seen as being able to provide solutions to contemporary legal problems. The philosophical-juridical foundation built in his fiqh is maqâsid alsharí $a b$ and al-maslahah al-mursalah while considering the level of legal sources as famous among mazhab scholars respectively; al-Qur'ân, al-Sunnah, qiyâs, al-istiḅlâs, al-'urf, alistishâh, etc., which are formulated as an operational instrument in istinbât al-ḅukm. Among Indonesian Muslims, there are differences in approach to the use of istinbât albukm; NU ulama use qawli approach, while Muhammadiyah ulama frequently use manhajî approach. Therefore, Zahro specifically believes that what he initiates is an attempt to reconcile approaches of different schools of Muslim law by highlighting istinbât manhajî as an option to establish an Islamic law.
\end{abstract}

Keywords: Istinbât al-ḥukm; Istinbât manhajî Islamic law.

\section{Pendahuluan}

Dalam sejarah tashr ${ }^{*}$ Islam, perkembangan berbagai disiplin keilmuan Islam ikut andil dalam membangun beberapa disiplin ilmu yang menunjang tradisi penetapan fiqh, terutama dalam aspek metodologis; 'ulum al-hadîth, 'ulum al-Qur'ân, usûl al-fiqh dan al-qawấid al-fiqhiyah. ${ }^{1}$ Perkembangan keilmuan ini sangat bermanfaat bagi

1 Perkembangan keilmuan Islam terjadi secara dinamis pada abad ketiga dan keempat hijriyah. Jika 'ulûm al-Qur'ân dan 'ulum al-ḥadîth menjadi keilmuan yang terkait dengan dua sumber pokok dalam penetapan hukum Islam, maka usûl al-fiqh 
pengembangan fiqh agar dapat merespons berbagai problematika kontemporer di saat al-Qur'ân dan hadîth sudah dalam kondisi yang purna semenjak Nabi Muhammad wafat. Pasca-fase tersebut, sejarah mencatat pergerakan dinamis perkembangan fiqh di kalangan umat Muslim. Era ijtihad menjadi tonggak awal lahirnya produk-produk fiqh sebelum era taqlid mengambil alih gerak dinamis ijtihad yang membawa perkembangan yang signifikan dalam bidang fiqh.

Fase taqlid melanda umat Islam dengan berbagai faktor yang melatari-nya. ${ }^{2}$ Fenomena taqlíd memang bukan hal yang sepenuhnya negatif. Ada sisi positif di dalamnya karena di fase ini ijtihad tidak total terhenti. Jika pada fase sebelumnya ijtihad berlangsung dengan sangat dinamis bahkan melahirkan berbagai metode ijtihad, maka pada fase taqlid ulama tinggal meneruskan-jika tidak dapat dikatakan mengikuti-apa yang telah dihasilkan para pendahulunya (pendapat atau qawl. ${ }^{3}$ Dari fenomena taqlìd ini memunculkan fenomena

dan qawâid al-fiqh menjadi pelengkapnya. Usûl al-fiqh merupakan nalar deduktif sedangkan al-qawâiid al-fiqhiyah lebih merupakan hasil dari nalar induktif dalam menggeneralisir fiqh yang mempunyai unsur keserupaan menjadi prinsip-prinsip hukum. Namun dalam perkembangannya, al-qawâiid al-fiqhîyah lebih mendapat perhatian dari para pemerhati fiqh kontemporer sebagai dasar hukum karena sifatnya yang praktis, sehingga qawâi id al-fiqhîyah dapat dijadikan dasar pengembangan fiqh baru. Lihat Abdul Mun'im Saleh, Hukum Manusia sebagai Hukum Tuhan: Berpikir Induktif Menemukan Hakikat Hukum Model al-Qawa'id al-Fiqhiyah (Yogyakarta: Pustaka Pelajar, 2009), 317-318.

2 Taqlíd diartikan sebagai "mengikuti pendapat orang yang diikuti tanpa mengetahui dasar yuridisnya". Lihat Abdul Hamid Hakim, Mabâdî Awwalìyah (Jakarta: Sa'adiyah Putra, t.th.), 21. Terdapat berbagai faktor yang melatarbelakangi fenomena taqlîd, di antaranya ketiadaan ulama (pada era pasca-kejatuhan Baghdad sebagai pusat Dinasti 'Abbâsîyah ke tangan Mongol) yang mengadakan kegiatan ijtihad mutlak secara dinamis seperti pada masa sebelumnya, sehingga hal ini menimbulkan persepsi pintu ijtihad telah tertutup. Muhammad al-Khuḍ̂rî̀ Bik, Târikkh al-Tashrî al-Islâmî (Beirut: Dâr al-Fikr, 1999), 367-368.

${ }^{3}$ Fase taqlíd atau dikenal dengan masa stagnasi diramaikan dengan tradisi menyusun sharḅ dan hâashîyah atas matn atau karya dari para imam mazhab. Tradisi sharḥ dan hâshîyah ini terjadi terutama di bidang fiqh di samping juga di bidang keilmuan lain seperti ilmu kalam. Dengan adanya tradisi ini, kegiatan intelektual dunia Islam tidak terhenti sama sekali. Di sisi lain, hal ini dipandang sebagai kemunduran karena hanya menjabarkan apa yang sudah dibahas oleh ulama pendahulu tanpa banyak memunculkan pendapat hukum terbaru yang independen dari para komentator kitab. Lihat Nurcholis Madjid, "Tradisi Syarah dan Hasyiyah dalam Fiqh dan masalah Stagnasi Pemikiran Hukum Islam” dalam Budhy Munawar Rahman, Kontekstualisasi Doktrin Islam dalam Sejarah (Jakarta: Paramadina, 1995) sebagaimana 
bermazhab dalam fiqh. Secara alamiah ulama yang memecahkan permasalahan hukum dengan bersandar atau kembali pada qawl (pendapat) imam yang diikutinya; menjadi tokoh mazhab yang membentuk jaringan mazhab yang diikuti oleh banyak orang. ${ }^{4}$

Pada masa awal fenomena bermazhab, terdapat banyak mazhab yang berkembang. Namun seiring waktu berjalan, berbagai mazhab tersebut tidak semuanya bertahan disebabkan banyak hal, sehingga pengikut mazhab tadi hanya tersisa beberapa saja jika dibandingkan dengan empat mazhab mainstream yang dikenal sekarang ini; Hanafìyah, Mâlikîyah, Shâfîìah dan Hanbalîyah. Mazhab-mazhab mainstream yang berkembang dan bertahan hingga kini mempunyai kekhasan metodologis dalam penggalian hukum hingga menghasilkan hasil akhir rumusan fiqh yang berbeda pula. ${ }^{5}$

Pergumulan cara bermazhab dikenal istilah talfíq atau metode ekletik dalam menyelesaikan permasalahan fiqh. Talfí dalam bermazhab menjadi hal kontroversial antara dilarang dan

dikutip dalam Ahmad Lutfi Maghfurin, Tradisi Syarah dan Hasyiyah dalam Fikib: Stagnasi Hukum Islam (Surabaya: Makalah Pascasarjana, 2013), 7-8.

${ }^{4}$ Mazhab pada awalnya hanya dimaksudkan sebagai pendapat salah seorang imam mujtahid tentang hukum suatu masalah sehingga mengikutinya disebut sebagai bermazhab secara qawli. Fenomena bermazhab seperti ini lahir dari sikap taqlíd terhadap para ulama pendahulunya yang malah justru tidak pernah mewajibkan pendapat mereka harus diikuti. Kemudian berkembang pula istilah bermazhab secara manhajî atau metodologis. M. Ali Hasan, Perbandingan Mą̧bab (Jakarta: Raja Grafindo Persada, 2003), 86. Dalam literatur lain disebutkan bahwa mazhab adalah pokok pikiran atau dasar yang digunakan oleh imam mujtahid dalam memecahkan masalah atau mengistinbatkan hukum Islam. Selanjutnya imam mazhab atau mazhab itu berkembang pengertiannya menjadi kelompok umat Islam yang mengikuti metode istinbât imam mazhab tertentu atau mengikuti pendapat imam mazhab tertentu tentang masalah hukum Islam. Lihat Huzaimah T. Yanggo, Pengantar Perbandingan Maz̧hab (Jakarta: Logos Wacana Ilmu, 1997), 72.

${ }^{5}$ Dunia Islam mengenal beberapa mazhab fiqh antara lain mazhab Hanafî, Mâlikî, Shâfîî, serta Hanbalî yang dikategorikan sebagai aliran Sunni. Selain itu terdapat mazhab fiqh beraliran Shî‘ah seperti Shî‘ah Imâmîyah (Ja'farîyah) dan Shî‘ah Zaidîyah. Mazhab-mazhab ini yang sampai sekarang masih bertahan dan banyak memiliki pengikut di kalangan umat Islam berbagai kawasan. Sedangkan mazhabmazhab yang tidak lagi bertahan antara lain mazhab al-Awzâî̀, al-Thawrî, al-Layth dan al-Tabarî. Mazhab-mazhab ini tidak dapat tersebar luas dan bertahan karena pengikut-pengikutnya jarang yang mengkodifikasikannya menjadi suatu buku. Lihat Hasan, Perbandingan Mazhab, 250-252. 
diperbolehkan. ${ }^{6}$ Namun pada dasarnya pembahasan tentang talfíq berpangkal pada fenomena taqlìd yang menghasilkan kesimpulan "pintu ijtihad telah tertutup" dan rasa ta 'asssub dalam bermazhab, sehingga bagi para pengikut mazhab tinggal mengambil pendapat dari para pemuka mazhab yang diikutinya tanpa melihat dan melirik pada pandangan mazhab yang lain. Namun berbagai permasalahan fiqh kontemporer yang terjadi terkadang tidak dapat diselesaikan hanya dengan kembali pada pendapat mazhab tertentu saja, yang mana bersumber dari berbagai literatur klasik produksi abad pertengahan Islam, sehingga bermazhab secara qawlî perlu dilengkapi dengan bermazhab secara manhaji. ${ }^{8}$

Ahmad Zahro (selanjutnya disebut Zahro) sebagai seorang pakar ilmu fiqh di Universitas Islam Negeri Sunan Ampel dan menjadi salah seorang tokoh yang produktif dalam menulis buku tentang berbagai solusi permasalahan hukum Islam kekinian, telah menyusun buku berjudul Fiqh Kontempoer. Menjawab 111 Masalah dan 33 Solusi Islami pada tahun 2012. Buku kumpulan tanggapan Zahro terhadap pertanyaan-pertanyaan dari masyarakat dalam bidang fiqh yang dilengkapi dengan rujukan berlandaskan pada al-Qur'ân, hadîth dan kaidah fiqh dengan metode istinbât manhajî. Untuk istilah terakhir, tulisan ini hendak mengfokuskan objek telaah yang akan diuraikan landasan metodologis dan praktis dari istinbât manhajı̂ tersebut dalam pandangan dan dipraktikkan oleh Zahro.

${ }^{6}$ Talfí menurut arti harfiahnya adalah tambal sulam, sedangkan menurut istilah diartikan sebagai mengambil pendapat dari seorang mujtahid kemudian mengambil lagi dari seorang mujtahid yang lain, baik dalam masalah yang sama maupun yang berbeda. Dengan kata lain talfiq adalah memilih pendapat dari berbagai pendapat yang berbeda dari kalangan ahli fiqh. Terjadi kontroversi antara ulama yang memperbolehkan maupun yang memperbolehkannya. Ibid., 89 .

7 Mengenai tertutupnya pintu ijtihad, oleh sebagian ulama dibenarkan karena memang ada sebagian orang yang tidak memiliki keahlian melakukan ijtihad, sehingga ijtihadnya menyimpang dari ajaran al-Qur'ân. Untuk hal itu maka ulama berteriak bahwa pintu ijtihad telah tertutup. Satria Efendi dalam Wacana Fiqh Sosial-70 Tahun KH. Ali Yafie, 145, sebagaimana dikutip dalam Musawwir, "Potret Mazhab-mazhab Fiqh dalam Peradaban Islam”, Istinbath, Vol. 3 (Desember, 2005), 114.

${ }^{8}$ Bermazhab secara manhajî dapat diartikan sebagai "mengikuti metode istinbât imam mazhab tertentu". Yanggo, Pengantar Perbandingan Mazhab, 72.

9 Ahmad Zahro, Figh Kontemporer Menjawab 111 Masalah + 33 Solusi Islami (Jombang: Unipdu Press, 2012), testimoni pada sampul belakang. 
Dalam buku Fiqh Kontemporer, Zahro-sebelum mengemukakan pendapat pribadinya tentang hukum sebuah permasalahanmenampilkan pula pendapat-pendapat ulama mazhab sebagai dasar perbandingan. Hal ini dalam pandangan penulis menunjukkan Zahro adalah faqîh yang juga bermazhab. Namun bagaimana bentuk mazhab yang diikuti Zahro? Secara sekilas dapat dikatakan bahwa ia lebih memilih bermazhab secara manhajî yang dinamis bahkan ia juga bertalfíq secara metodologis dalam batas tertentu sesuai kebutuhan. Dengan demikian dapat diasumsikan bahwa Zahro telah melakukan pengembangan pola bermazhab manhajî dengan menggunakan istinbât manhajî sebagai metode perumusan fiqh dengan didukung dalil alQur'ân, hadîth maupun kaidah fiqh. Pengembangan pola istinbât manhajî seperti ini menjadi salah satu langkah dalam merespons berbagai permasalahan kontemporer yang membutuhkan jawaban fiqh yang tidak cukup jika hanya diatasi dengan pola bermazhab qawli.

Dari uraian tentang fenomena bermazhab, talfíq, pengembangan bermazhab baik secara qawlî maupun manhajh, dikoneksikan dengan pemikiran fiqh Zahro mengenai berbagai permasalahan fiqh kontemporer, telah menarik perhatian penulis untuk mengkaji lebih dalam tentang aspek metodologis perumusan hukum (figh) menurut penulis buku Fiqh Kontemporer yang disebutkan menggunakan metode istinbât manhajî dalam testimoninya. Ketertarikan ini berdasar pula pada pentingnya meng-upgrade pemikiran fiqh pada aspek metodologis dari tokoh atau pakar fiqh Indonesia untuk memperkaya khazanah keilmuan Islam di negeri ini.

\section{Sketsa Biografis Ahmad Zahro}

Ahmad Zahro dilahirkan di kabupaten Nganjuk Jawa Timur, tepatnya di dusun Tuko desa Sanggrahan kecamatan Prambon pada 7 Juni 1955. Ayah ia bernama KH. Imam Sardjuni Hasan $(A l m)$ dan ibu ia bernama Siti Aminatun. Zahro terlahir sebagai putra kedua dari delapan bersaudara. Masa kecilnya dihabiskan dalam kondisi penuh keprihatinan karena keadaan keluarganya yang terbilang sangat paspasan kala itu, sehingga kesederhanaan menjadi hal yang akrab baginya sejak kecil. Kekagumannya pada sosok sang ayah yang pekerja keras dan serius dalam urusan pendidikan anak-anaknya, membuat Zahro menanamkan sikap birr al-wâlidayn sejak dini kepada anakanaknya, dengan harapan kelak menjadi anak-anak yang bertakwa 
pada Allah, berbakti kepada orang tua dan berani menghadapi segala kesulitan hidup. ${ }^{10}$

Saat ini Zahro menjadi guru besar UIN Sunan Ampel Surabaya dalam bidang fiqh sekaligus menjadi rektor sebuah universitas Islam swasta di Jombang UNIPDU (Universitas Pesantren Tinggi Darul Ulum). ${ }^{11}$ Sosok Zahro sebagai seorang pendidik meninggalkan kesan tersendiri bagi para murid dan mahasiswanya. Di mata mereka, ia dikenal sebagai seorang dosen yang disiplin dan tegas dalam kegiatan pembelajaran. Salah satu ciri khas pembelajarannya adalah ketika mahasiswa memasuki hari pertama perkuliahan, mahasiswa akan diberi batas waktu yang sama dalam menyelesaikan dan mengumpulkan tugas kuliah walaupun waktu presentasinya berbeda. Hal ini dapat menjadi tolok ukur kedisiplinan dan kesungguhan para mahasiswa dalam menunaikan tugas.

Dalam menanggapi berbagai pertanyaan mengenai permasalahan fiqh, Zahro memiliki formula jawaban tersendiri sehingga orang akan dengan mudah mengikuti alur berpikirnya. Berbagai permasalahan yang ditanyakan kepadanya akan diidentifikasi dan diklasifikasi terlebih dahulu sebelum dijawab. Salah satu ungkapan Zahro yang diingat oleh para mahasiswanya yaitu, "Kalau dalam masalah ibadah, maka kata kuncinya al-nîyah wa al-tâ'ah (niat dan taat), sedangkan dalam masalah mu'âmalah, maka kata kuncinya al-"aqd wa al-maslahab". Pembentukan formula jawaban seperti ini dapat mempermudah untuk mengidentifikasi dan mengklasifikasi berbagai permasalahan yang diajukan. ${ }^{12}$

Zahro melewati masa kecilnya di bawah pengasuhan orang tuanya. Sebelum menempuh pendidikan formal di jenjang sekolah dasar pada umur dua belas tahun, ia mendapat pengajaran langsung dari ayahnya beberapa pelajaran keagamaan melalui ngaji (menelaah) kitab-kitab kuning yang merupakan kajian khas dalam dunia pesantren. ${ }^{13}$ Selepas pendidikannya di tingkat dasar, ia melanjutkan pendidikannya di MAAIN Nglawak dan PGAN selama enam tahun di Kediri. ${ }^{14}$ Kemudian melanjutkan rihlah pendidikannya ke Pondok Pesantren Putra "al-Fattah" Mangunsari Tulungagung pada tahun 1979. Di

\footnotetext{
10 Ahmad Zahro, Wawancara, Sidoarjo, 10 Oktober 2014.

${ }^{11}$ Http:/ / rektor.unipdu.ac.id/cv/ (3 Agustus 2014).

12 Ibid.

${ }^{13}$ Zahro, Wawancara, Sidoarjo, 10 Oktober 2014.

${ }^{14}$ Ibid.
} 
pesantren ini, ia menghafal al-Qur'ân dan mempelajari kitab-kitab keIslaman di tengah kesibukannya menjalani kuliah di Fakultas Tarbiyah IAIN Sunan Ampel di Tulungagung yang ia tempuh berbarengan sampai memperoleh gelar sarjana muda pada tahun 1979. ${ }^{15}$ Kehidupan di pesantren yang sangat sederhana dijalani olehnya dengan penuh kesungguhan. Puasa-bahkan puasa karena ketiadaan makanan-dan tirakat menjadi hal biasa bagi Zahro. Pendidikan pesantren yang relatif terjangkau biayanya, menjadi salah satu faktor yang mendorong ia memilih "mondok" di tengah kehidupan ia yang sangat sulit. ${ }^{16}$

Selepas dari pendidikannya di Tulungagung, Zahro melanjutkan pendidikannya hingga memperoleh gelar sarjana lengkap di Fakultas Tarbiyah IAIN Sunan Ampel di Malang pada 1983. Setelah itu, ia mulai melakukan rihlah tarbiyah ke Timur Tengah. Dua negara yang menjadi tempat ia menempuh pendidikan selanjutnya adalah Mesir dan Sudan. ${ }^{17}$ Di Mesir, pada pagi hari ia menjalani kuliah hingga meraih Sarjana Lengkap Fakultas Adab Universitas al-Azhar di Kairo Mesir pada 1985, sedangkan pada sore harinya, ia mengikuti kelas Takhașsus Tafsîr Ayât al-Aḥkâm (spesialisasi tafsir ayat-ayat hukum) pada Majma al-Buhûth al-Islâmîyah li al-Ažbâr di Kairo Mesir pada tahun yang sama. ${ }^{18}$ Setelah dari Mesir, ia melangkahkan kaki dalam rangka menuntut ilmu di Sudan mengambil pendidikan diploma ' $A \hat{\imath}$ pada Ma'had al-Khurtum ad-Dauly li al-Lughah al-'Arabîyah (Institut Bahasa Arab Internasional) di Khartoum, Sudan pada tahun 1986. Sedangkan gelar Magister di universitas yang sama ia raih setahun kemudian pada tahun $1987 .{ }^{19}$

Beberapa karya akademik dihasilkan oleh Zahro, antara lain: Feminisme dan Fiqih Perempuan, Fiqib: Perspektif Ilmiah dalam Bingkai Ukhunwah; Fundamentalisme antara Barat dan Dunia Islam: Telaah Fiqib Politik; Hifdh al-Qur'ân dan Beberapa Dimensinya; Ijtihad Jaringan Islam Liberal; Ijtihad Pendidikan: Rekonstruksi Sistem Pendidikan; Islam dan Kebangsaan: Telaah Fiqih Siyasah; Kompromi Ber Tedul Fithriy; Konsep Maslabah Ath-Thufiy; Metode dan Prosedur Istinbat Hukum Islam; Shalat dalam Perspektif Fiqih (Shalat Formal) dan Shalat Spiritual; Ulama sebagai

\footnotetext{
${ }^{15} \mathrm{Http}: / /$ rektor.unipdu.ac.id/cv/ ( 3 Agustus 2014).

16 Zahro, Wawancara, Sidoarjo, 10 Oktober 2014.

${ }^{17} \mathrm{Http}: / /$ rektor.unipdu.ac.id/cv/(Agustus 2014).

18 Ibid.

${ }^{19}$ Ibid.
} 
Perekat Ukbuwwab; Desakralisasi Kitab Fiqih sebagai Upaya Reformasi Pemahaman Hukum Islam; Tradisi Intelektual NU; dan Figh Kontemporer: Menjawab 111 Masalah + 33 Solusi Islami.

Dari berbagai karya tersebut terdapat sebuah karya monumental yang menjadi rujukan banyak pihak yang melakukan kajian tentang tradisi intelektual NU. Karya ini berupa buku berjudul Tradisi Intelektual NU yang diadaptasi dari disertasinya yang berjudul Lajnah Babsul Masail NU. ${ }^{20}$ Selain buku ini, Zahro membukukan juga berbagai pandangan ia tentang fiqh kontemporer dalam sebuah buku berjudul Figh Kontemporer: Menjawab 111 Masalah + 33 Solusi Islami. Saat ini telah terbit buku Fiqh Kontemporer jilid II yang menjadi lanjutan dari edisi sebelumnya. Dua bukunya-Tradisi Intelektual NU dan Fiqh Kontemporer_bagi penulis merupakan sumber utama dalam memahami konsep istinbât manbajı̂ dan aplikasinya sebagai metode perumusan hukum Islam menurut Zahro. Dari buku Tradisi Intelektual $N U$ penulis dapat memahami apa dan bagaimana metode istinbât manhajî dijadikan metode yang luwes dan adaptif terhadap perkembangan permasalahan kontemporer. Kesinambungan historis atas landasan sosiologis dan yuridis metode istinbât manhajî ini dapat ditemui salah satunya dengan membaca isi dan analisa buku ini. Sedangkan buku Fiqh Kontemporer memudahkan penulis memahami dengan lebih baik produk pemikiran figh Zahro yang disebut mengunakan metode istinbât manbajî.

Zahro memiliki karakteristik pemikiran yang otentik dan independen. Hal ini dapat dipahami dari pemetaan yang ia lakukan terhadap berbagai permasalahan fiqh yang ada. Dalam berbagai tulisan dan kajiannya, dapat ditemukan beberapa pemetaan permasalahan, termasuk permasalahan kontemporer yang dapat dikaji melalui fiqh. Fiqh kontemporer menurutnya mencakup keseluruhan aspek kehidupan yang dipandang dari perspektif fiqh baik berupa bidang ibadah, mu'âmalah, mawârîth, jinâyah, siyâsah, maupun akidah.

20 Zahro dalam pengantar buku ini, mengatakan bahwa secara substantif kajian dalam buku ini mengarah pada studi tentang Lajnah Bahsul Masa'il NU yang merupakan satu forum kajian yang membahas berbagai persoalan keagamaan Islam di lingkungan organisasi yang secara fiqh berafiliasi pada empat Imam mazhab (mazhab Hanafî, Mâlikî, Shâfîî, dan Hanbalî). Lebih spesifik lagi, buku ini mencoba melakukan analitis kritis terhadap kitab-kitab yang menjadi rujukan dalam forum bạ̣th al-masâ'il yang biasa disebut al-kutub al-mu'tabarah, metode istinbât hukum yang digunakan, serta keputusan hukum fiqh yang dihasilkannya. Ahmad Zahro, Tradisi Intelektual NU (Yogyakarta: LKiS, 2004), ix. 
Singkatnya, menurut Zahro istilah kontemporer digunakan untuk menunjuk arti segala hal yang dialami manusia di era sekarang ini. ${ }^{21}$ Pemetaan Zahro terhadap berbagai permasalahan fiqh terlihat ketika ia mengetengahkan solusi tentang ruwatan untuk menolak bala' (bencana). Dari pendapatnya, penulis memandang bahwa ia adalah pemikir Islam moderat yang dicirikan dengan ketiadaan ekstremitas dalam pandangan-pandangannya, dapat memilah mana bagian ajaran Islam yang esensial dan mana yang merupakan "bungkus", sehingga tidak dengan mudah "memvonis" segala sesuatu yang tidak ditemukan dalam tradisi awal Islam sebagai sesuatu yang "sesat" dan berlabel bid'ah. Sifat moderat atau tawassut memang menjadi bagian dari sikap Ahl al-Sunnah wa al-Jamâ'ah selain itidâl, tasâmuh, tawẫun, ta'âmun, dan amr ma'rûf naby munkar. ${ }^{22}$

Dalam berbagai pembahasannya, Zahro juga sering mendasari kajiannya dengan maqâsid al-shari'ah dan al-maslaḅah al-mursalah. ${ }^{23}$ Pemahaman tentang maqâsid dan al-maslaḥah digunakan olehnya untuk menguak lebih lanjut dasar filosofis sebuah permasalahan hukum fiqh agar ditemukan solusi yuridis yang tepat. Dalam bab selanjutnya akan diketengahkan beberapa misal praktis yang dilakukan Zahro berkenaan dengan maqâsid dan al-maslahah yang menjadi concern dari ușul al-fiqh yang menemukan korelasinya dengan penggunaan al-qawấid al-fiqhîyah sebagai instrumen istinbât manhajî.

Selanjutnya Zahro melihat bahwa permasalahan fiqh memerlukan solusi jawaban yang menggunakan berbagai perspektif untuk mendapatkan sudut pandang yang lebih menyeluruh. Dalam sebuah solusi terhadap permasalahan akad nikah di depan jenazah, ia memandang permasalahan ini dari perspektif fiqh (hukum Islam), perspektif sosiologis (kemasyarakatan), perspektif psikologis

${ }^{21}$ Zahro, Wawancara, Sidoarjo, 10 Oktober 2014.

22 Tim Penyusun, Aswaja An-Nabdliyah (Surabaya: Khalista, 2010), 64-68. Sejarah pemikiran Islam di Indonesia selalu diramaikan dengan adanya tiga golongan besar (fundamental Islam, liberal Islam, dan moderat Islam) yang terkadang saling menyerang baik dalam ranah pemikiran bahkan tidak jarang berujung pada "perang" fisik. Jika kedua golongan pertama (fundamental dan liberal Islam) dalam posisi saling berhadapan, kehadiran golongan moderat dapat menjadi penengah walau pada saat yang sama dipandang dengan pandangan mencurigakan dari kedua golongan yang lain. Fakta sejarah ini berakar pula dari sejarah masa lalu yang menghasilkan berbagai firqah dalam bidang teologi maupun mazhab dalam bidang fiqh.

23 Zahro, Wawancara, Sidoarjo, 10 Oktober 2014. 
(kejiwaan), serta perspektif teologis (akidah). Dari pertimbangan berdasar perspektif-perspektif tersebut, ia sampai pada kesimpulan bahwa walaupun akad nikah di depan jenazah secara fiqh tetap sah selama syarat rukunnya terpenuhi, tetapi tidak direkomendasikan dilangsungkan dan lebih baik dihindari karena antara manfaat dan madaratnya, lebih banyak madaratnya baik secara sosiologis, psikologis apalagi teologis. ${ }^{24}$

Zahro juga mengadakan kategorisasi fiqh menjadi beberapa bagian, yaitu: fiqh formal (yuridis), fiqh ibadah (ritual), fiqh mu'âmalah atau sosial (kemasyarakatan), fiqh kultural (kebudayaan), fiqh spiritual (tasawuf) serta fiqh moral (etika). Dalam pandangan penulis, kategorisasi ini dilakukan untuk mempermudah dalam memahami posisi sebuah permasalahan jika dilihat dari kategori fiqh tertentu atau gabungan dari beberapa kategori fiqh. Kaidah yang sering disampaikan Zahro mengenai kategori fiqh ini antara lain, "kalau dalam masalah ibadah, maka kata kuncinya al-nîyah wa al-tâ'ah. Sedangkan dalam masalah mu'âmalah, maka kata kuncinya al-'aqd wa almaslahah. ${ }^{25}$ Selain itu, ia juga membuat rumusan untuk memudahkan dalam memandang permasalahan mu'âmalah, yaitu "niat, cara, dan akibat". ${ }^{26}$ Segala permasalahan di bidang mu'amalah dapat ditinjau hukumnya dengan mempertimbangkan ketiga hal tersebut. Sebagai ilustrasi dapat dikatakan suatu perbuatan (mu'âmalab) dinyatakan sah dan diperbolehkan jika niat atau motivasi yang mendasarinya baik, cara melaksanakannya sesuai dengan aturan yang ditetapkan, dan akibat dari perbuatan tersebut tidak merugikan atau menyalahi ketentuan. Jika salah satu dari "niat, cara, dan akibat" terdapat kesalahan, maka perbuatan tersebut dinyatakan tidak sah atau dilarang.

Zahro dalam beberapa kesempatan juga menyampaikan adanya perbedaan antara ijmấ dan ittifâq, juga antara qiyâs dan ilhâq. Ijmấ menurutnya pada masa sekarang ini sudah sulit sekali ditemukan, karena ijmấ menurutnya adalah kesepakatan para mujtahid/faqîh secara global melewati batas wilayah. Misal ijmâ' pada era kontemporer sekarang ini, hanya untuk permasalahn yang yang dihadapi secara global seperti tentang keharaman narkoba. Perbedaan pandangan dan pemikiran ulama atau lembaga pemegang otoritas

24 Zahro, Fiqh Kontemporer, 488-491.

25 Zahro, Wawancara, Sidoarjo, 10 Oktober 2014.

${ }^{26}$ Ibid. 
hukum Islam di berbagai negara Muslim juga menambah sulit tercapainya ijmâ:. Oleh karena itu, Zahro mengakui adanya kesepakatan yang bernilai lokal, baik dalam lingkup organisasi tertentu maupun negara bangsa tertentu. Kesepakatan jenis ini diidentifikasi sebagai ittifâq. Misalnya dalam kasus ittifâq kalangan Muhammadiyah tentang keharaman rokok, serta ittifâq kalangan Nahdlatul Ulama (NU) tentang kemakruhan rokok. ${ }^{27}$ Dengan demikian antara Muhammadiyah dan NU saja (yang notabene berada dalam wilayah geografis negara yang sama) tidak terjadi kesepakatan bersama, apalagi kesepakatan antar-ulama di berbagai belahan dunia, tentu lebih sulit terwujud.

Selain qiyâs, Zahro juga mengelaborasi metode ilhâq yang "serupa" dengan metode qiyâs dalam cara kerjanya untuk menyelesaikan problematika hukum Islam. ${ }^{28}$ Dalam diskursus keilmuan Islam metodologis (ușul al-fiqh dan al-qawấid al-fiqhîah), term qiyâs dan ilhâq diidentifikasi persamaan dan perbedaannya. Walaupun terlihat sama cara kerjanya, kedua metode ini memiliki perbedaan. Jika dalam qiyâs terdapat asl dan far', serta terdapat hukkm al-așl dan 'illat bukkm al-asl, maka dalam ilhâq juga terdapat aşl dan far', serta terdapat juga hukm alasl, namun yang menyambungkan antara bukm al-așl dan far'u bukanlah 'illat tapi hikmah yang lebih lentur dan luas jangkauannya. Jika asl dalam qiyâs berupa naṣs (al-Qur'ân dan hadîth), maka aṣl dalam ilhâaq adalah fiqh yang telah memiliki ketetapan hukum (hal ini diketahui dari ibarat kitab-kitab fiqh yang memuatnya). Dengan perspektif lain, qiyâs adalah cara kerja dalam usûl al-fiqh, sedangkan ilhâqq lebih dikenal sebagai cara kerja dalam al-qawấid al-fiqhîyah.

Sebagai ulama yang sering mendapatkan pertanyaan dari masyarakat tentang berbagai konsekuensi hukum fiqh atas permasalahan yang mereka hadapi, Zahro tidak menegasikan adanya kesenjangan antara aturan formal perundang-undangan dengan aturan fiqh dalam pelaksanaannya. Dalam pandangan penulis, Zahro memahami betul bagaimana sebagian masyarakat Muslim kita lebih "patuh" pada fiqh "murni" daripada kepada aturan perundangundangan yang notabene juga "fiqh" yang berbaju legislasi modern. Dalam menyikapinya, ia mulai menjawab permasalahan tersebut berdasar perspektif fiqh "murni" yang lebih "mengena" dalam kemantapan hati untuk mengamalkannya seraya memberikan

27 Zahro, W awancara, Sidoarjo, 10 Oktober 2014.

${ }^{28} \mathrm{Ibid}$. 
pengertian dan pemahaman bahwa pemerintah mengeluarkan peraturan perundang-undangan adalah bentuk kebijakan demi kemaslahatan rakyat sesuai kaidah tasarruf al-imâm 'alâ al-ra'îyah manût bi al-maslahah, di samping keharusan kita sebagai rakyat untuk hanya patuh kepada Allah dan Rasul-Nya, juga ditekankan patuh kepada $u \hat{\imath}$ al-amr yang tak lain adalah pemerintah. ${ }^{29}$

Sebagaimana telah tersebut sebelumnya dan berdasarkan pemaparan Zahro dalam buku Figh Kontemporer, bahwa sebelum memaparkan pendapat pribadi, ia tidak jarang memaparkan berbagai pendapat dari mazhab-mazhab yang ada maupun tokoh ulama kontemporer lainnya sebagai bahan perbandingan. Hal ini dalam pandangan penulis menunjukkan adanya etika keilmuan dengan melihat khazanah pemikiran Islam masa lalu sebagai bahan pengembangan pemikiran Islam kontemporer, sehingga mata rantai keilmuan Islam selalu terjaga dan berkesinambungan. Dalam perspektif lain, dapat dikatakan Zahro ingin menunjukkan apa dan bagaimana mazhab dipahami secara qawlî dan manhajî serta berguna bagi para pencari hukum sesuai kapasitasnya masing-masing, jika termasuk kalangan awam maka silahkan untuk bermazhab qawli, sedangkan bagi kalangan khâsș/intelektual menjadi kelaziman untuk bermazhab manhajî. ${ }^{30}$

29 Zahro mengakui adanya potensi dualisme dalam masyarakat Muslim di Indonesia tentang kepatuhan mereka pada fiqh dan hukum formal di Indonesia. Menurutnya, idealnya masyarakat mengikuti aturan yuridis formal. Menanggapi hal ini, ia menyatakan bahwa dalam hal pernikahan yang dicatatkan di KUA, maka perceraiannya juga harus dilakukan di Pengadilan Agama. Jika pernikahan dilakukan secara siri (dengan segala risiko yang harus dihadapi), maka jika memenuhi syarat adanya dua saksi dalam talaknya maka dihukumi sah talaknya. Ia juga menyebut dualisme ini dengan sah secara fiqh tapi tidak sah secara bukum negara dan menekankan sosialisasi tentang dampak negatif dari hal ini. Ibid.

30 Zahro ketika ditanya tentang pendapatnya tentang bermazhab dan talfíq, menyatakan bahwa bagi orang awam wajib bermazhab dengan cara taqlíd, karena tanpa itu mereka tidak dapat mengetahui hukum (fiqb), sedangkan bagi kalangan intelektual yang menguasai metodologi istinbât al-hukm dan memenuhi persyaratan maka selazimnya bagi mereka untuk menjadi 'mujtahid' fatwa atau minimal bermazhab dengan cara ittibâ'. Taqlîd diartikan sebagai mengikuti pendapat ulama tanpa mengetahui dasar hukumnya, sedangkan ittibâ' menyaratkan adanya pengetahuan tentang dasar hukum pendapat yang diikuti muttabi' tersebut. Mengenai talfíq, Zahro menyatakan para ulama berbeda pendapat tentang hal ini. Yang jelas, Zahro tidak mempermasalahkan talfíq asalkan dilakukan dengan hati yang taat dan pengetahuan tentang dalil-dalilnya. Zahro, Wawancara, Sidoarjo, 10 Oktober 2014. 
Dua term yakni mazhab qawlì dan mazhab manhajî memang lebih dikenal sebagai term yang berlaku di kalangan NU. Zahro dalam disertasinya menyebutkan bahwa istinbât LBM NU menggunakan metode qawlì, ilhâqî serta manbajî. Hal ini menunjukkan bahwa istilah bermazhab qawli adalah bermazhab dengan mengikuti pendapat "jadi" dari para ulama terdahulu, sedangkan bermazhab manhajî mengikuti pedoman istinbât ulama terdahulu. ${ }^{31}$ Ia juga mengakui metode perumusan hukum Islam dalam berbagai mazhab figh adalah warisan dan jasa besar ulama mazhab terdahulu yang berguna bagi generasi sekarang untuk mengadakan telaah hukum (istinbât). Berdasarkan pengakuannya, ia adalah intelektual yang bermazhab. Seahli apapun, ia tetap memandang bahwa pemikiran fiqhnya harus tetap dalam koridor mazhab yang telah ada yang saat ini terakumulasi dalam al-madhâbib al$\operatorname{arba}^{\prime} a b^{32}$

Zahro juga menyatakan pintu ijtihad tidak pernah "tertutup", namun untuk membukanya diperlukan kualifikasi bagi ulama yang akan berijtihad dan memang tidak banyak orang yang memilikinya. Menurutnya, di antara syarat tersebut yang paling penting untuk dimiliki oleh mujtahid, yaitu: pengetahuan tentang al-Qur'ân dan ilmuilmunya, pengetahuan tentang hadîth dan ilmu-ilmunya, pengetahuan tentang bahasa Arab, pengetahuan tentang usûl al-fiqh, kaidah fiqh dan ilmu penunjangnya serta bertakwa kepada Allah. ${ }^{33}$ Lebih lanjut ia mengartikan hukum Islam sebagai "hukum yang bersumber dari alQur'ân dan hạaîth dan/atau tidak bertentangan dengan al-Qur'ân dan hadîth". Hal ini ia sampaikan karena adanya al-maslaḥah al-mursalah yang diakomodir sebagai metode istinbât yang sah. ${ }^{34}$

Menanggapi pertanyaan penulis tentang formalisasi hukum Islam di Indonesia, Zahro menyatakan formalisasi hukum Islam menjadi

\footnotetext{
31 Ibid.

32 Ibid.

33 Ibid. Menurut Zahro, kriteria bertakwa pada Allah menjadi syarat yang sangat penting bagi seorang mujtahid, dan seorang fâsiq tidak dapat diterima pendapatnya. Zahro memandang bahwa adagium yang pernah disampaikan oleh Sayyidina Alî b. Abî Tâlib, unz̧ur mâ qâl wa lâ tandur man qâl (lihatlah apa yang dikatakan, jangan melihat siapa yang mengatakannya) yang dulu sesuai dengan kondisi zamannya, pada saat ini kurang tepat untuk dipegang karena saat ini kita tidak boleh begitu saja melihat atau memperhatikan ucapan seseorang tanpa mengetahui bagaimana rekam jejaknya, sehingg adagium yang lebih tepat adalah unzur mâ qâl wa lâ tanžur man qâl. Ibid.

${ }^{34}$ Ibid.
} 
peraturan perundang-undangan jika dapat dilaksanakan maka itu baik. Akan tetapi hal itu memerlukan dakwah terlebih dahulu pada masyarakat, sehingga mereka sadar hukum Islam. Kalaupun hukum Islam tidak dapat diakomodir dalam bentuk formal tekstual, minimal hukum Islam dapat dipelihara konteksnya dalam kehidupan bermsyarakat di Indonesia. ${ }^{35}$

Dari berbagai telaah penulis terhadap peta dan karakteristik pemikiran figh Zahro, dapat dikatakan bahwa Zahro adalah salah satu dari ulama Indonesia kontemporer yang moderat ${ }^{36}$ dan lebih berkiblat pada paradigma Islam kontekstual. Kegemarannya dalam membuat kategorisasi dalam fiqh - terutama dalam buku Figh Kontemporerditujukan agar para pembaca lebih mudah memahami dan mengidentifikasi berbagai permasalahan fiqh, sehingga lebih mudah bagi mereka menemukan jawaban hukumnya. Inti segala jawabannya atas berbagai permasalahan fiqh berdasar pada maqậid al-sharíah dan al-maslahah al-mursalah. ${ }^{37}$ Metode yang dikembangkan sebagai metode perumusan hukum Islam adalah metode istinbât manhajî yang merupakan pengembangan pola bermazhab, terutama di kalangan NU yang pernah ia jadikan objek penelitian.

Zahro juga menyatakan di antara dua ormas Islam terbesar di Indonesia, NU dan Muhammadiyah pada saat ini telah terjadi "kemiripan". Menurutnya, pada dasarnya perbedaan antara NU dan Muhammadiyah bukan dalam masalah keagamaan yang prinsipil melainkan pada penerimaan mereka atas kultur keberagamaan umat atau penyikapan terhadap budaya. Pada saat ini, generasi muda Muhammadiyah mulai menerima kultur keberagamaan umat Islam di

\footnotetext{
35 Ahmad Zahro, Wawancara, Sidoarjo, 10 Oktober 2014.

36 Dalam menanggapi polarisasi aliran pemikiran Islam di Indonesia antara moderat, liberal, maupun fundamental, Zahro menyatakan bahwa ia di satu waktu dikatakan sebagai liberal dan di waktu yang lain dikatakan sebagai konservatif. Namun ia tetap mengakui keterikatannya pada mazhab. Menanggapi Islam liberal yang diikuti oleh sebagian anak muda NU, ia menyatakan tetap berhubungan baik dengan mereka. Ia tidak setuju dengan kalangan yang bersikap terlalu keras pada mereka. Zahro lebih mengedepankan jalur dialogis dalam menghadapi mereka seperti mengimbanginya dengan menulis di berbagai media sehingga muncul dialog yang konstruktif, sehingga bisa dinilai oleh masyarakat. Ibid.

37 Zahro mengakui bahwa dalam bidang pemikiran hukum Islam, ia terinspirasi oleh ulama kontemporer yang saat ini juga menjadi rujukan banyak pihak karena keluwesan pandangan-pandangannya, di antaranya adalah Yusuf al-Qardhawi dan Wahbah al-Zuhaylî. Menurutnya, pemikiran kedua tokoh itu sangat egaliter dan "cair". Ibid
} 
Indonesia, sehingga mereka kini juga mulai mengembangkan dakwah kultural yang semenjak awal menjadi bidang garapan kalangan NU. Begitu juga sebaliknya, dalam tradisi intelektual NU mulai muncul penggunaan dasar penetapan hukum melalui dasar al-Qur'ân dan hadîth yang pada mulanya menjadi ciri khas intelektual dalam Muhammadiyah. Dengan disahkannya metode manhaji-yang mendasarkan pada al-Qur'ân dan hadîth melalui metode ulama terdahulu-sebagai metode istinbât di kalangan NU, membuat NU dan Muhammadiyah bertemu di satu titik yang sama dalam beristinbat. Begitu pula dengan penerimaan Muhammadiyah atas kultur keberagamaan umat Islam di Indonesia melalui dakwah kultural juga menjadikannya dekat dengan kalangan NU. ${ }^{38}$

\section{Landasan Sosiologis Yuridis Istinbât Manhajî}

Sebagai representasi dari produk pemikiran fiqh, buku Fiqh Kontemporer karya Zahro mendasarkan jawaban-jawaban hukum dari berbagai permasalahan dengan rujukan hukum yang bersandar pada al-Qur'ân, hadîth, dan kaidah fiqh. Formula ini dikatakan sebagai metode istinbât manbajî. Lahirnya istilah dan konsep istinbât manbajî sebagai metode perumusan hukum Islam menurut Zahro dapat ditelusuri landasan sosiologis dan yuridisnya. Hal ini penulis lakukan dengan menelusuri karya ilmiah Zahro sebelumnya yang dapat menunjukkan historisitas lahirnya metode istinbât manhajî ini, yakni dengan membaca hasil penelitian Zahro dalam karya disertasinya yang berjudul "Lajnah Bahsul Masa'il Nahdlatul Ulama 1926-1999: Telaah Kritis Terhadap Keputusan Hukum Fiqh". ${ }^{39}$ Dalam kajiannya tentang Lembaga Bahsul Masail (LBM) NU, ${ }^{40}$ Zahro menyebutkan beberapa

\footnotetext{
38 Pada awalnya, kajian intelektual NU hanya berhenti pada kitab-kitab mu'tabarah yang dijadikan acuan dasar hukum. Dalam perkembangannya mulai merambah dalil al-Qur'ân dan hadîth. Ibid.

39 Disertasi ini diterbitkan oleh LKiS dengan judul Tradisi Intelektual NU: Lajnah Babtsul Masa'il 1926-1999.

40 Nahdlatul Ulama adalah suatu jam‘îyah dînîyah Islâmîyah (organisasi keagamaan Islam) yang didirikan di Surabaya pada 16 rajab 1344 H/31 Januari 1926 M. Lihat Anggaran Dasar NU Bab I Pasal 1,3 dan 4 hasil Muktamar XXX di Kediri, 21-27 Nopember 1999 sebagaimana dikutip dalam Ahmad Zahro, Tradisi Intelektual NU: Lajnah Babtsul Masa'il 1926-1999 (Yogyakarta: Lkis, 2004), 17. Nahdlatul Ulama (NU) menganut paham abl al-sunnab wal jamá'ah, sebuah pola pikir yang mengambil jalan tengah antara ekstrem 'aqlî (rasionalis) dengan kaum ekstrem naqlî (skripturalis). Karena itu sumber pemikiran bagi NU tidak hanya al-Qur'an, alSunnah, tetapi juga menggunakan kemampuan akal ditambah dengan realitas
} 
metode ijtihad atau istinbât NU dalam menghasilkan keputusan-

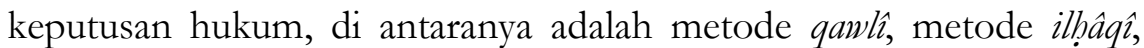
dan metode manbajî. ${ }^{41}$

Metode qawli adalah cara istinbât hukum yang digunakan oleh ulama atau intelektual NU dalam Lajnah Bahsul Masail (LBM) ${ }^{42}$ dengan mempelajari masalah yang dihadapi, kemudian mencari jawabannya pada kitab-kitab fiqh dari empat mazhab, dengan mengacu dan merujuk secara langsung pada bunyi teksnya. Atau dengan kata lain mengikuti pendapat-pendapat yang sudah "jadi" dalam lingkup mazhab tertentu. Metode ini merupakan metode pertama yang ditempuh dalam LBM dan telah diterapkan sejak semula pada tahun 1926 walaupun belum disebutkan secara eksplisit. ${ }^{43}$ Apabila metode qawlî tidak dapat dilaksanakan karena tidak ditemukan jawaban tekstual dari suatu kitab mu'tabar, maka dilakukan apa yang disebut ilhâq al-masâil bi nazẩirihâ, yakni menyamakan hukum suatu kasus atau masalah yang belum ada ketetapan hukumnya dalam kitab dengan kasus atau masalah serupa yang telah dijawab oleh kitab (telah ada ketetapan hukumnya) atau menyamakan dengan pendapat yang sudah jadi. Metode ini dikenal dengan metode ilhâqqî. Metode ilhââ dalam praktiknya menggunakan prosedur dan persyaratan mirip qiyâs, oleh karenanya dapat juga dinamakan metode qiyâsî versi $\mathrm{NU}^{44}$ Metode ketiga dalam LBM NU adalah metode manbajî. Metode

empirik. Cara berpikir semacam itu dirujuk dari pemikir terdahulu, seperti Abu. Hasan al-Ash'arî dan Abû Manșûr al-Mâturidî dalam bidang teologi. Kemudian dalam bidang fiqh mengikuti empat mazhab; Ḥanafî, Mâlikî, Shâfíi, dan Hanbalî. Sementara dalam bidang tasawuf, mengembangkan metode al-Ghazâlî dan Junaid Al-Baghdâdî, yang mengintegrasikan antara tasawuf dengan syariat. Gagasan kembali ke khittah pada tahun 1984, merupakan momentum penting untuk menafsirkan kembali ajaran Ahlussunnah Wal Jamaah, serta merumuskan kembali metode berpikir, baik dalam bidang fikih maupun sosial. Serta merumuskan kembali hubungan NU dengan negara. Gerakan tersebut berhasil membangkitkan kembali gairah pemikiran dan dinamika sosial dalam NU. Lihat http:/ /www.nu.or.id/a,public-m,static-s, detail-lang,id-ids,1-id,7-

t,paham+keagamaan-.phpx. (9 Oktober 2014).

${ }^{41}$ Zahro, Tradisi Intelektual NU, 115-132.

42 LBM NU bertugas membahas masalah-masalah maudu'ýah (tematik) dan waqi îyah (aktual) yang akan menjadi Keputusan Pengurus Besar Nahdlatul Ulama. Lihat http://www.nu.or.id/a,public-m,static-s,detail-lang,id-ids,1-id,14-t,lembaga-.phpx.

(9 oktober 2014).

${ }^{43}$ Ibid., 118.

44 Ibid., 121. 
manhajî adalah suatu cara menyelesaikan masalah keagaamaan yang ditempuh LBM dengan mengikuti jalan pikiran dan kaidah penetapan hukum yang telah disusun imam mazhab. ${ }^{45}$

Ketiga bentuk metode tersebut menurut penelusuran Zahro telah diterapkan dalam pengambilan keputusan hukum dalam LBM NU sebelum Munas Alim Ulama di Bandar Lampung pada 21-25 Juni 1992. Munas tersebut meresmikan penggunaan ketiga metode tersebut. Hal ini menunjukkan dinamika dalam penggunaan metode penggalian dan penetapan suatu keputusan LBM dari hanya digunakannya metode qawlî, beranjak pada kemungkinan terlibatnya penalaran dalam format metode ilhâqû, bahkan lebih maju lagi dengan disepakati dan diresmikannya penggunaan metode manhaji. ${ }^{46}$

Dari penelusuran Zahro terhadap produk keputusan hukum LBM NU, baik sebelum maupun setelah Munas di Bandar Lampung pada 1992 sampai pada tahun 1999, ditemukan beberapa keputusan yang diidentifikasi menggunakan metode qawlî sebanyak 362 masalah (84,6\%), yang menggunakan metode ilhââ̂ sebanyak 33 masalah $(7,7 \%)$, dan yang menggunakan metode manhajî sebanyak 8 masalah $(1,9 \%)$. Selebihnya sebanyak 25 masalah $(5,8 \%)$ tidak jelas metode istinbât-nya. ${ }^{47}$ Terjadinya kesenjangan intensitas atau frekuensi penggunaan ketiga metode tersebut menunjukkan bahwa penggunaan metode qawlî tetap mendapat porsi terbesar. Sedangkan kedua metode lainnya yakni metode ilhâqû dan metode manhajî menempati urutan setelahnya secara berurutan. Metode manhajî menjadi metode yang paling rendah intensitas atau frekuensi penggunaannya. Hal ini menimbulkan kesan bahwa keinginan di kalangan intelektual NU untuk beranjak dari bermazhab secara qawli menuju bermazhab secara manhajî masih menjadi tantangan ke depan menghadapi berbagai persoalan kontemporer yang tidak cukup diatasi hanya dengan pola bermazhab qawlit, sehingga diperlukan pengembangan lebih lanjut dengan bermazhab secara manhaji melalui metode istinbât manhajî.

\footnotetext{
${ }^{45}$ Ibid., 124. Bermazhab menjadi pilihan NU sehingga penelitian tentang LBM NU tidak dapat dipisahkan dari kajian tentang mazhab. Dalam perjalanan sejarah dan seleksi alam dengan berbagai faktor penyebabnya, di antara berbagai mazhab fiqh yang beragam, hanya empat mazhab yang eksis. Pada akhirnya keempat mazhab fiqh yakni Ḥanafî, Mâlikî, Shâfîî, dan Hanbalî yang menjadi pijakan bermazhab oleh NU. Keempat mazhab tersebut memiliki metode istinbât yang berbeda-beda.

${ }^{46}$ Ibid., 270.

${ }^{47}$ Ibid., 170.
} 
Upaya pengembangan pola bermazhab manhajî di kalangan NU akan berjalan dengan baik melalui mekanisme ijtihâd jama $\hat{\imath}$. Hal ini dapat diwujudkan oleh LBM dengan melibatkan berbagai pakar dan ahli di berbagai bidang yang menjadi objek pembahasan masalah selain para ulama dan intelektual NU yang ada. Namun begitu tidak menutup kemungkinan para intelektual NU melakukan pengembangan pola bermazhab manhajî melalui mekanisme ijtihâd fardî sebagaimana dilakukan oleh Zahro.

Dari uraian di atas dapat dikatakan bahwa istinbât manhajî memiliki landasan sosiologis dibuktikan adanya berbagai persoalan kontemporer yang tidak cukup jika hanya diatasi dengan pola bermazhab qawlî. Realitas sosial kemasyarakatan pada era kontemporer saat ini memunculkan banyak problem yang memerlukan jawaban hukum segera. Jika faqîh atau seorang ulama yang dimintai fatwa masih harus mencari jawabannya di berbagai kitab karya ulama terdahulu dan belum tentu menemukan jawabannya, maka penggunaan istinbât manhajî sebagai metode perumusan hukum Islam menjadi solusinya.

Secara yuridis, landasan hukum penggunaan istinbât manbajî sebagai metode perumusan hukum Islam menurut Zahro adalah diresmikannya metode manhajî ini dalam Munas Alim Ulama di Lampung pada tahun 1992. Dengan demikian, Zahro termasuk ulama Indonesia yang telah berupaya melakukan pengembangan metode istinbât manhajî ini. Bukti konkret upaya itu terlihat dalam buku Fiqh Kontemporer karyanya.

Secara sosiologis, dapat dikatakan istinbât. manhajî adalah konsep dan teori dalam beristinbat atau merumuskan hukum Islam yang lahir dari perjalanan tradisi intelektual NU yang mengalami perkembangan dari hanya menggunakan metode qawlî, metode ilhâq $\hat{\imath}$ dan menemukan titik akhirnya di metode manhajì. Kebutuhan akan istinbât manhajî (istinbât dengan metode manhâjî) sebagai metode perumusan hukum Islam dalam perjalanan sejarahnya didasari oleh tumbuh berkembangnya berbagai masalah kontemporer yang tidak cukup jika hanya diatasi dengan metode qawlî dan ilhâquî sehingga metode manhajî menemukan signifikasinya.

\section{Pengertian Istinbât Manhajî Menurut Ahmad Zahro}

Setelah membaca historisitas landasan sosiologis-yuridis metode istinbât manbajî, perlu diketengahkan pengertian istinbât manbajî menurut Zahro dengan melakukan pengkajian mendalam hasil 
pemikiran fiqh Zahro dalam buku Fiqh Kontemporer yang menurut penulis sangat representatif untuk mengurai konstruk metodologis yang dikembangkan olehnya. Sebagaimana hantaran dalam kertas kerja ini, bahwa rumusan-rumusan hukum atas berbagai permasalahan fiqh dihasilkan Zahro menggunakan metode istinbât manhajì, karena ia mendasarkan jawaban-jawaban hukumnya pada al-Qur'ân, ḥadîth dan kaidah fiqh. Selain itu, Zahro juga menyatakan metode manhaj seperti yang digunakan dalam bahsul masâil NU—adalah metode penetapan hukum Islam/fiqh berdasarkan metode istinbât yang dipakai oleh para imam mazhab sebelumnya.

Karena metode ini bertumpu pada metode istinbât al-hukm para imam mazhab sebelumnya, maka perlu diketahui bagaimana para imam mazhab sebelumnya ber-istinbât, metode dan dalil apa saja yang mereka gunakan. Hal ini dilakukan agar kita dapat mendeskripsikan dengan baik metode istinbât manhajî yang dimaksud. Untuk menjawab pertanyaan yang muncul tadi, kita dapat merujuk buku Tradisi Intelektual NU karya Zahro yang juga menelaah hal ini sebagai bagian dari pembahasannya tentang metode manhajî yang dipakai oleh babth al-masâil NU dalam menetapkan hukum permasalahan-permasalahan yang ada. Zahro menyatakan NU memilih untuk bermazhab dalam fiqh. Mazhab yang dipedomani oleh NU adalah al-madhâbib al-arba'ah yaitu: mazhab Hanafî, Mâlikî, Shâfîî, serta Hanbalî. Bermazhab menjadi pilihan NU, sehingga penelitian tentang LBM NU tidak dapat dipisahkan dari kajian tentang mazhab. Alasan historis NU menetapkan empat mazhab yang diakomodir sebagai sumber istinbât, karena dalam perjalanan sejarah dan seleksi alam dengan berbagai faktor penyebabnya, hanya empat mazhab tersebutlah yang mampu bertahan dengan ragam metode istinbat yang berbeda-beda.

Kalau diuraikan, ragam metode yang dimiliki oleh empat mazhab dimaksud sebagai berikut:

1. Mazhab Hanafî dengan tokohnya Abû Hanîfah menggunakan metode (dalil yang digunakan) secara hierarkis yaitu: al-Qur'ân, alHadîth al-Ṣaḥ̂h, aqwâl al-ṣahabât, qiyâs, al-istiḥsân, ijmâ' dan al-'urf.

2. Mazhab Mâlikî dengan tokohnya Mâlik b. Anas dalam menetapkan hukum menggunakan sembilan metode secara hierarkis yaitu: al-Qur'ân, al-ḥadîth al-sabîh, ijmâ' al-Sahâabat, 'amal abl al-Madinah, fatwâ Șahâabat, qiyâs, al-istihsân, al-masâlị̣ al-mursalah, dan al-dharâ'i. 
3. Mazhab Shâfîî dengan tokohnya Muhammad b. Idrîs al-Shafî̀i secara hierarkis menggunakan empat metode yaitu: al-Qur'ân, alḥadîth al-sahịh, ijmấ, aqwâl al-sahâbat, dan qiyâs.

4. Mazhab Hanbalî dengan tokohnya Aḥmad b. Hanbal menggunakan delapan metode penetapan hukum secara hierarkis yaitu naṣs (al-Qur'ân dan al-Sunnah bingga ke tingkat ḥadîth da'îf asal bukan hadîth munkar), ijmâ', qiyâs, al-masâalih al-mursalah, al-istihsân, alżarâ'i', fatwâ sababat, dan al-istiş̧âb.

Dari pengertian istinbât manhajî menurut Zahro di atas, dapat diketahui bahwa dalam melakukan istinbât manhajî terdapat beberapa instrumen yang dibutuhkan, antara lain: dalil al-Qur'ân, hadith maupun kaidah fiqh rumusan sederhana ini mempermudah seorang faqîh dalam menerapkan penggunaan metode ilmiah dalam usahanya menggali dan merumuskan hukum Islam. Namun demikian, penerimaan terhadap validitas hasil istinbât manhajı̂ tidak terlepas pada uji validitas terhadap instrumen-instrumen istinbât berikut ini:

1. Al-Qur'ân

Kehujjahan al-Qur'ân sebagai dalil utama dalam istinbât manhajî tidak diragukan lagi. Para ulama sependapat bahwa al-Qur'ân adalah sumber utama hukum Islam. Hal ini secara filosofis dilandasi oleh prinsip al-ḅukm li Allâh yang berarti bahwa hakikat hukum (Islam) adalah hukum Allah.

Dalam diskursus filsafat hukum Islam, ${ }^{48}$ Secara ontologis, hukum Islam berbeda dengan sistem hukum lain yang berkarakteristik sekuler. Hukum Islam berkarakteristik ilâhŷah dan telah sempurna; pembahasan tentang hakikat ontologisnya telah selesai. Hukum Islam merupakan sistem ketuhanan yang mendahului negara Islam dan tidak didahului olehnya, mengontrol masyarakat Islam dan tidak dikontrol olehnya. Hanya Allah penguasa bagi negara Islam. Dialah yang

48 Pendekatan filsafat dalam hukum Islam atau filsafat hukum Islam dipakai dengan hati-hati oleh para ahli hukum Islam, dikarenakan tidak ditemukannya kata filsafat dalam sumber-sumber hukum Islam. Pada awalnya, istilah filsafat atau falsafah diidentikkan dengan istilah hikmah karena dalam arti semantiknya, keduanya samasama berarti kebijaksanaan. Apabila para filsuf Islam menggunakan kata hikmah sebagai murâdif dari kata filsafat atau falsafah, demikian pula penyusun-penyusun kitab Asrâr al-Sharîah menggunakan kata hikmah sebagai julukan bagi asrâr al-aḅkâm (rahasia-rahasia hukum), sehingga jika terdengar istilah filsafat atau falsafah hukum Islam langsung terbayang hikmah shalat, hikmah puasa dan sebagainya tanpa terbayang tentang usûul al-aḥkâm dan qawâiid al-ạ̣kâm. T.M. Hasbi Ash Shiddieqy, Falsafah Hukum Islam (Jakarta: Bulan Bintang, 1990), 25-26. 
memberikan pada negara Islam kekuatan tertinggi untuk mengontrol, mempunyai otoritas mutlak dan independen karena tiada hukum kecuali hanya milik Allah. ${ }^{49}$

Kajian aspek epistemologis hukum Islam menghasilkan sebuah disiplin ilmu yaitu ușul al-fiqh sebelum akhirnya bermitra dengan kajian al-qawâid al-fiqhiyah. Secara aksiologis, hukum Islam tidak diragukan lagi keberadaannya, yaitu sebagai hukum yang berorientasi kemaslahatan dunia maupun akhirat. Namun untuk memahami atau menjelaskan kembali kedudukan hukum Islam sebagai hukum yang sâliḥ li kull zamân wa makân, diperlukan kajian dalam bahasa falsafi ${ }^{50}$ tentang segala aspek tersebut.

Al-Qur'an yang merupakan Kalâm Allâh diyakini umat Islam sebagai sumber hukum utama karena dengan memahami al-Qur'ân (berdasar pada prinsip al-ḅukm li Allâh), kita dapat mengetahui hukum dari permasalahan yang kita hadapi. Walaupun prinsip utama ini disepakati semua kalangan fuqaha, namun dalam dataran praktis. Mereka berbeda dalam "memahami" al-Qur'ân, sehingga terjadi permasalahan dengan dasar hukum yang sama dari al-Qur'ân, namun fuqahâ berbeda pandangan dalam menetapkan hukumnya. Hal ini diduga disebabkan perbedaan mereka dalam menggunakan turuq dilalat al-alfầ, sehingga menyebabkan perbedaan fuqaha dalam menetapkan hukumnya.

2. Hạaîth

Kehujjahan hadîth sebagai dalil kedua setelah al-Qur'ân diterima oleh para ulama walaupun terdapat perbedaan dalam tingkat penerimaan mereka terhadap hadîth-ḥadîth selain yang bernilai șặih. Kedudukan hadîth sebagai dalil hukum mendampingi al-Qur'ân tidak terlepas dari peran al-Shâfî̀ dalam membuat pondasi dalil hukum

49 Muhammad Muslehuddin, Filsafat Hukum Islam dan Pemikiran Orientalis Studi Perbandingan Sistem Hukum Islam, terj. Yudian Wahyudi Asmin et.al (Yogyakarta: Tiara Wacana, 1997), 13.

50 Dalam falsafat al-tashrî terdapat kajian tentang usûl al-ạ̣kâm yang menjadi pegangan ulama dalam membina siyasah tashrî antara lain al-qiyâs, al-istiḥsân, al-urf, al-masaliḥ al-mursalah, sadd al-dharîah dan al-istiṣ̣âb. Ușull al-ạ̣kâm tersebut secara umum menegaskan adanya kebaikan atau kemaslahatan yang ingin dicapai dalam hukum. Kemaslahatan inilah yang menjadi ruh dari kajian filsafat hukum Islam dan dapat digunakan sebagai prinsip keluwesan dan keluasan sharî́ah Islam menghadapi perubahan zaman. Lihat Yusuf al-Qardhawi, Keluwesan dan Keluasan Syariat Islam Menghadapi Perubahan Zaman, Terj. Tim Pustaka Firdaus (Jakarta: Pustaka Firdaus, 1996). 
yang dapat dijadikan pegangan dalam berijtihad. Al-Shâfîî dalam alRisâlab menguraikan panjang lebar tentang dasar filosofis dari kehujjahan hadîth sebagai dalil hukum. Hal ini dilakukan al-Shâfîî di tengah "kacau"-nya metode istinbât di antara dua pihak yang berseberangan antara abl al-ḩadith dan abl al-ra'y. Ia menginginkan ulama dalam berijtihad harus melewati tahap-tahap yang ada. Tahaptahap tersebut adalah mula-mula ijtihad bersandar pada dalil alQur'ân, setelah itu hadîth baru melibatkan kerja akal (ra'y) yang dalam pandangan al-Shâfîî terwujud dalam bentuk qiyâs (analogi deduktif).

\section{Kaidah Fiqh}

Kaidah fiqh sebagai salah satu instrumen istinbât manhajî pada awalnya menjadi perangkat metodologis yang belum begitu "diterima" oleh semua kalangan. Hal ini tidak terlepas dari proses pembentukan atau lahirnya kaidah fiqh melalui nalar induktif (istiqrâ). Kajian-kajian induktif fiqh (sehingga menghasilkan al-qawâ'id al-fiqhiyah dalam berbagai kitab atau karya ulama tentangnya) berpangkal pada kaidah jalb al-masâlih dan dar' al-mafâsid. ${ }^{1}$ Berbeda dengan al-Qur'ân dan hadîth yang berkedudukan sebagai nașs dan menjadi sumber hukum yang dapat dideduksi, kaidah fiqh adalah hasil induksi dari berbagai fiqh yang senada menjadi kaidah-kaidah hukum. Hal ini memunculkan pertanyaan "Apakah sesuatu yang lahir dari proses induksi dapat dijadikan dalil atau dideduksi untuk menghasilkan furû' baru?".

Pertanyaan di atas dijawab oleh penelitian yang dilakukan oleh Abdul Mun'im Saleh dalam disertasinya di Program Pascasarjana UIN Sunan Ampel yang berjudul "Fiqh dan Nalar Induktif: Kajian atas alQawâ‘id al-Fiqhîyah dalam Perspektif Induksi”. Dalam mengawali

51 Bisri Mustafa, Tarjamah Nadam al-Farâid al-Babîyah li Abî Bakar al-Ahdal (t.t: Menara Kudus, t.th), 13. Dalam menalar hukum Islam, sebagai telaah perbandingan antara filsafat hukum Islam, usûul al-fiqh maupun al-qawâid al-fiqhîyah dapat dikatakan bahwa kajian filsafat hukum Islam sangat membantu seorang Muslim dalam memahami hukum Islam dan memperluas cakrawala berpikir bagi siapa saja yang menekuninya. Bukan saja dalam wilayah hukum Islam, namun juga bahasan-bahasan dalam filsafat hukum yang selama ini dianggap berada di luar jangkauan hukum Islam. Peranan filsafat hukum Islam dalam menalar hukum Islam, bersanding sejajar dengan peran ușul al-fiqh (dalam hal ini al-qawâid al-usûlîyah) dan al-qawâìd al-fiqhîyah. Ilustrasi kemitraan antara ușul fiqh dan al-qawâi id fiqhîyah dalam menalar hukum Islam dapat digambarkan secara kronologis bahwa usûl al-fiqh mendeduksi fiqh dari sumber-sumber wahyu, kemudian al-qawâid al-fiqhîyah mengkonstruksi kerangka umum yang melandasi fiqh menjadi metodologi penalaran hukum Islam. Skema lain yang dapat di ajukan adalah: nașs, ușull al-fiqh, fiqh/furû', al-qawâid al-fiqhîyah, furû́ baru. Saleh, Hukum Manusia sebagai Hukum Tuban, 277. 
pembahasannya, Saleh menguraikan bagaimana kaidah fiqh lahir sebagai ilmu metodologis mendampingi ușul al-fiqh. Al-qawấid alfiqhiyah merupakan kekayaan keilmuan Islam yang bisa disebut sebagai model penemuan maqâsid al-sharîah atau "nilai-nilai fundamental", karena ilmu ini merupakan aspek prosedural dari pengelolaan maslaḥah yang telah disepakati sebagai tujuan hukum Islam. Rumusan-rumusan kaidahnya yang bersifat universal-abstrak meniscayakan digunakannya metode induktif, berangkat dari partikular-partikular hasil pemikiran fiqh menuju kesimpulan-kesimpulan general-universal yang berbasis pada kesamaan-kesamaan dan padanan-padanan atau yang diistilahkan dengan al-ashbâh wa al-naz̧âir, istilah yang merupakan nama lain dari ilmu al-qawâi id al-fiqhîyah. Kaidah-kaidah dari ilmu ini dilukiskan oleh pemikir kontemporer sebagai lukisan yang baik tentang prinsipprinsip fiqh dan pedoman bagi penyusunan hukum positif (cabangfurû). Para fuqaha perintis dan penyusun ilmu ini dengan demikian telah menyediakan fasilitas untuk memandu langkah-langkah penalaran hukum dalam berbagai tingkatannya. ${ }^{52}$

Selanjutnya Saleh menyatakan:

Keterangan di atas hanya untuk menunjukkan bahwa persepsi orang tentang ijtihad selama ini tidak memperhitungkan peranan al-qawa id al-fiqbîah. Berpikir mengembangkan hukum Islam tanpa menyertakan fasilitas yang diberikan ilmu ini adalah menyalahi logika kemajuan ilmu pengetahuan yang selalu merupakan akumulasi pengetahuan dari masa lalu untuk dijadikan pijakan kemajuan masa kini dan mendatang. ${ }^{53}$

Berangkat dari fenomena di atas, Saleh dalam penelitiannya bermaksud menjelaskan makna dari segala aktivitas pemikiran hukum di luar apa yang secara konvensional disebut ijtihad yang biasanya dipersepsi hanya merupakan aktivitas nalar deduktif atas sumber tekstual (nass) dan secara tipikal biasa dipahami sebagai bidang peranan ilmu usul fiqh saja. Penelitiannya mengkaji makna pelibatan nalar induktif dalam pengembangan hukum Islam atau fiqh sebagaimana berlangsung dalam kajian al-qawấid al-fiqhîyah. ${ }^{54}$

\footnotetext{
52 Ibid., 11. Kaidah fiqh merupakan rumusan umum dari beragam persoalan furûyyah yang tak terhitung jumlahnya dan memiliki keserupaan illat yang bersesuaian dengan dalil nas dan prinsip-prinsip dasar sharî́ah. Lihat Abdul Haq, Ahmad Mubarok, Agus Ro'uf, Formulasi Nalar Figh Telaah Kaidah Fiqh Konseptual (Surabaya: Khalista, 2006), 7.

53 Ibid., 12.

${ }^{54}$ Ibid.
} 
Uraian kronologis pembahasan Saleh tentang peranan kaidah figh dalam penalaran hukum di atas memberi pengertian bahwa kaidah fiqh mempunyai peran yang sangat signifikan bagi para pegiat fiqh kontemporer khususnya untuk melakukan penalaran atau telaah hukum. Jika selama ini, usul fiqh mempunyai banyak metode penalaran hukum yang beragam baik yang disepakati maupun yang diperselisihkan, maka kaidah fiqh berhasil mengakomodir berbagai metode penalaran tersebut ke dalam uraian-uraian kaidah yang sederhana dan mudah untuk diterapkan. Untuk memberi gambaran distingtif dalam hal ini dapat dilihat melalui tabel berikut:

\begin{tabular}{|c|c|c|c|}
\hline Aspek & $\begin{array}{c}\text { Filsafat Hukum } \\
\text { Islam }\end{array}$ & $\begin{array}{c}\text { Al-Qawâ'id al- } \\
\text { Ușûlîyah }\end{array}$ & $\begin{array}{c}\text { Al-Qawâlid al- } \\
\text { Fiqhîyah }\end{array}$ \\
\hline Pembuat & Filsuf & $\begin{array}{l}\text { Ahli usûl al-fiqh } \\
\text { (Usûliyyin) }\end{array}$ & "Ahli fiqh (faqîh) \\
\hline Kelahiran & $\begin{array}{l}\text { Sejalan dengan } \\
\text { perkembangan } \\
\text { hukum }\end{array}$ & Sebelum fiqh ada & Setelah fiqh jadi \\
\hline Bahan & $\begin{array}{l}\text { Ontologi, } \\
\text { epistemologi, } \\
\text { aksiologi Hukum } \\
\text { Islam }\end{array}$ & $\begin{array}{l}\text { Kelaziman } \\
\text { bahasa, filsafat } \\
\text { bahasa, logika }\end{array}$ & $\begin{array}{l}\text { Masalah-masalah } \\
\text { fiqh yang } \\
\text { diklasifikasi }\end{array}$ \\
\hline Target & $\begin{array}{l}\text { Menalar Hukum } \\
\text { Islam secara aqli } \\
\text { dari sumbernya }\end{array}$ & $\begin{array}{l}\text { Memahami lafad } \\
\text { naș (kaidah } \\
\text { deduksi) } \\
\text { Menyelesaikan } \\
\text { kasus yang } \\
\text { mempunyai naș }\end{array}$ & $\begin{array}{l}\text { Memahami kasus } \\
\text { Menyelesaikan } \\
\text { kasus yang tidak } \\
\text { mempunyai nass }\end{array}$ \\
\hline Fungsi & $\begin{array}{l}\text { Menjelaskan } \\
\text { kembali hakikat } \\
\text { (apa, bagaimana } \\
\text { dan untuk apa) } \\
\text { hukum secara } \\
\text { falsafi }\end{array}$ & Menggali hukum & $\begin{array}{l}\text { Menyimpulkan } \\
\text { hukum menjadi } \\
\text { prinsip hukum }\end{array}$ \\
\hline Daya cakup & Seluruh kasus & Seluruh kasus & $\begin{array}{l}\text { Sebagian satuan } \\
\text { kasus/kulliyah } \\
\text { dan akthariyah }\end{array}$ \\
\hline Sifat & Spekulatif & $\begin{array}{l}\text { Kebenarannya } \\
\text { formal (pasti) }\end{array}$ & $\begin{array}{l}\text { Kebenarannya } \\
\text { material, bersifat } \\
\text { luwes dan } \\
\text { fleksibel }\end{array}$ \\
\hline
\end{tabular}

Prosedur dan Signifikansi Istinbât Manhajî dalam Fiqh 
Istinbât manhajì dapat dilakukan dengan mendasarkan jawaban hukum atas berbagai permasalahan pada sumber hukum tertinggi yakni al-Qur'ân. Dalam waktu yang bersamaan atau mengiringinya, hadith digunakan sebagai sumber kedua baik untuk menjelaskan lebih lanjut maksud dari al-Qur'ân, memerinci hukumnya atau menjelaskan apa yang belum secara eksplisit dijelaskan oleh al-Qur'ân. Di samping kedua sumber tersebut, kaidah fiqhîyah—termasuk juga kaidah ușulîyah_-digunakan sebagai pelengkap argumentasi.

Dari instrumen istinbât manhajî menurut Zahro, kaidah fiqhîyah disebut sebagai dasar ketiga setelah al-Qur'ân dan hadîth. Dalam kajiannya tentang LBM NU, Zahro juga menyebut bahwa Munas Alim Ulama di Bandar Lampung mempopulerkan sebuah metode istinbât hukum manakala metode qawlî dan ilhâqûे tidak dapat digunakan, yaitu apa yang disebut metode bermazhab secara manhaji dengan menelusuri dan mengikuti metode istinbât hukum secara manhajî yang ditempuh oleh mazhab empat. Hal ini dibuktikan dengan jawaban LBM NU dalam keputusan Kongres/Muktamar X pada tanggal 13-18 April 1935 di Surakarta. Dalam menjawab pertanyaan tentang hukumnya orang memelihara anak yatim fakir miskin dan sebagainya dari hasil pertandingan sepakbola, pertunjukan dan sebagainya, LBM menjawabnya dengan berdasar pada kaidah fiqhiyah daf' al-mafâsid muqaddam 'alâ jalb al-masâlị̣. (menghindari kerusakan lebih didahulukan daripada upaya memperoleh kemaslahatan). Jawaban tersebut tidak mencantumkan dalil dari suatu kitab ataupun memberikan argumentasi detail.

Dengan demikian, Zahro menganalisa bahwa jawaban hukum tersebut adalah melalui proses:

Setelah tidak dapat dirujukkan pada teks suatu kitab mu'tabar, juga tidak dapat di-ilhâq-kan pada kepada hukum suatu masalah yang mirip dan telah terdapat rujukannya dalam sebuah kitab mu'tabar, maka digunakan metode manhajî dengan mendasarkan jawaban mula-mula pada al-Qur'ân, setelah tak ditemukan lalu pada hadîth, dan begitu seterusnya yang akhirnya sampailah pada jawaban dari kaidah fiqh, daf' al-mafâsid muqaddam 'alâ jalb al-masâliḥ (menghindari kerusakan lebih didahulukan daripada upaya memperoleh kemaslahatan). Hal demikian dimungkinkan karena prosedur istinbât hukum bagi metode manhajı̀ adalah dengan mempraktikkan kaidahkaidah usul fiqh dan kaidah-kaidah fiqh. ${ }^{55}$

55 Ibid., 126-127. 
Formulasi sederhana tentang instrumen dan prosedur istinbât manhajî yang mendasarkan hukum pada dalil al-Qur'ân, hadîth dan kaidah fiqh di atas (sebagaimana penulis dapatkan dalam keterangan dalam buku Figh Kontemporer menurut Zahro adalah untuk memudahkan pengungkapan, karena dalam argumentasi hukum yang disampaikan Zahro dalam buku tersebut lebih banyak berupa dalil alQur'ân, hadîth serta kaidah fiqh. Namun hal ini tidak menafikan penggunaan dalil dan metode istinbât lain dari imam mazhab (yang menjadi rujukan dalam istinbât manhaji) ${ }^{56}$

Dalam argumentasi hukumnya Zahro juga menggunakan dalil: ijmâ' (dan ittifâq), metode qiyâs (dan ilhâa), al-istihsân, al-mașlạ̣ah almursalah, al-urf, dan lain sebagainya. Dengan melihat rumusan hukum dalam pemikiran fiqh Zahro yang menggunakan berbagai metode istinbât lintas mazhab, penulis melihat adanya talfí $q^{57}$ metodologis dalam batas tertentu sesuai kebutuhan. Menanggapi pertanyaan penulis tentang talfiq , ia menyatakan bahwa hal itu menjadi perbedaan pendapat di kalangan ulama. ${ }^{58}$ Dalam pandangannya, talfíq boleh dilakukan jika kita tahu masalahnya, tahu dalilnya, dan mantap

\footnotetext{
56 Ahmad Zahro, Wawancara, Sidoarjo, 10 Oktober 2014.

57 Talfíq secara etomologis berarti melipat sesuatu menjadi satu, atau mempertemukan sesuatu menjadi satu, secara operasional bermakna "beramal dalam suatu masalah menurut hukum yang merupakan gabungan dari dua mazhab atau lebih" atau menyatukan dua qawl dari dua mazhab yang berbeda ke dalam persoalan tertentu, sehingga menjadi satu komponen hukum yang tidak menjadi pendapat (qaw) bagi dua mazhab tersebut. Lihat Ibrahim Hosen, "Memecahkan Permasalahan Hukum Baru" dalam Haidar Bagir dan Syafiq Basri (eds.) Ijtihad Dalam Sorotan (Bandung: Mizan, 1996), 36 dan Sahal Mahfudh, Nuansa Fiqh Sosial (Yogyakarta: LKiS, 2003), 36.

58 Perbedaan pendapat mengenai talfí bersumber dari dan terkait erat dengan boleh tidaknya pindah dari satu mazhab ke mazhab lainnya. Dalam hal ini setidaknya ada tiga pendapat: Shâfîîyah melarangnya sama sekali, Hanafiyah memperbolehkannya tanpa syarat, dan Mâlikîyah memperbolehkannya dengan syarat. Lihat Zahro, Tradisi Intelektual NU, 139-140. Di kalangan NU, talfíq sudah mulai melonggar. Untuk halhal yang bersifat praktis, bagi orang awam tetap tidak diperkenankan talfiq sebagaimana dipegangi oleh Shâfi'îyah, sedang bagi yang terpelajar dan ulama, mereka boleh mengikuti golongan Mâlikîyah yang memperkenankan talfíq asal tidak dalam satu qadîyah/kasus. Adapun dalam hal metodologi mereka cenderung kepada ulama Hanafiyah yang memperbolehkan talfiq . Hal ini terlihat dari pelaksanaan metode manhajî yang dalam prakteknya tidak secara konsisten menelusuri secara terpisah metode istinbât hukum masing-masing mazhab empat, melainkan memilih secara selektif metode atau dalil yang diyakini benar dan tepat. Ibid., 141.
} 
hatinya.$^{59}$ Lebih lanjut ia menyatakan bahwa prosedur istinbât manbajı̂ harus dilakukan dengan "setia" dengan apa yang dilakukam oleh para ulama, tidak boleh mendahulukan yang lain dari al-Qur'ân (dan hadith). Selanjutnya Zahro menyatakan bahwa dikarenakan dalam permasalahan kontemporer sulit menemukan landasan ijmâ'-nya, maka ia langsung mencari landasan hukumnya dalam al-qawấid al-fiqhîyah. ${ }^{60}$ Hal itulah yang menyebabkan Zahro lebih memilih untuk menyederhanakan bahasa tentang dasar argumentasinya sebagai berikut:

Buku Fiqh Kontemporer: Menjawab 111 Masalah merupakan karya yang disusun dengan pola tanya jawab, sebagai jawaban dari berbagai permasalahan terkini yang banyak ditanyakan oleh masyarakat dalam berbagai diskusi dan pengajian yang ia asuh. Buku ini disusun dengan bahasa yang sangat sederhana dan mudah dipahami oleh semua kalangan, dilengkapi dengan rujukan hukum yang bersandar pada al-Qur'ân, Hadîth dan kaidah fiqh dengan metode Istinbât manhajî. ${ }^{61}$

Istinbât manhajî dengan instrumen-instrumennya yang dilakukan secara prosedural memiliki signifikasi sebagai metode perumusan hukum Islam. Hal ini berdasar pada pola atau tata cara istinbât al-ḥukm dalam metode istinbât manbajî yang dilakukan dengan menelusuri dasar hukumnya secara hierarkis dalam al-Qur'ân, al-hadîth al-sahîh, ijmât, qiyâs, dan berbagai metode lain yang dikenal dalam berbagai mazhab. Pola istinbât manhajî seperti ini memudahkan seorang faqîh dalam menemukan jawaban hukum atas berbagai permasalahan yang dihadapi oleh umat. Hal ini disebabkan keterbatasan yang dimiliki oleh kitab-kitab fiqh klasik yang terikat dengan historisitas ruang dan waktu saat kitab-kitab tersebut disusun. Permasalahan era kontemporer saat ini ada yang belum dikenal pada masa saat kitabkitab klasik tersebut disusun. Tentu hal ini menyebabkan upaya memperoleh jawaban hukum melalui metode qawli tidak dapat menjawab seluruh permasalahan kontemporer tersebut. Di sinilah signifikasi istinbât manhajî sebagai metode perumusan hukum Islam terlihat.

Istinbât manhajî juga menjadi metode perumusan hukum Islam alternatif yang dapat digunakan untuk ber-istinbât menghasilkan fatwa

\footnotetext{
${ }^{59}$ Zahro, Wawancara, Sidoarjo, 10 Oktober 2014.

${ }^{60}$ Ibid.

${ }^{61}$ Zahro, Fiqh Kontemporer, sampul belakang.
} 
bagi intelektual Muslim yang bermazhab seperti halnya Zahro. Ia sebagai ulama kontemporer mengakui keterikatannya pada mazhab, walaupun lebih pada bermazhab secara manhajî dengan mengembangkan pola istinbât manhajî sebagai metode perumusan hukum Islam. Ia juga sangat menghargai jasa besar para ulama mazhab yang telah mewariskan berbagai metode istinbât yang bermacam-macam sehingga berguna bagi generasi setelahnya, salah satunya sebagai instrumen istinbât manhajî.62 Menurutnya, diharapakan metode ini menjadi titik temu antara NU dan Muhammadiyah dalam hal istinbât hukum. ${ }^{63}$ Hal ini dalam pandangan penulis dapat lebih mencairkan "ketegangan" antara dua ormas Islam tersebut yang dalam banyak tulisan diidentikikasi sebagai golongan tradisionalis dan modernis, walaupun identifikasi tersebut saat ini perlu ditinjau ulang.

\section{Penutup}

Dalam menjawab permasalah-permasalahan fiqh kontemporer, Ahmad Zahro mendasarkan jawaban-jawaban hukumnya berdasarkan dalil al-Qur'ân, al-Hadith, pandangan fuqaha serta kaidah fiqh dengan mengedepankan aspek al-maslaḥah dan maqâsid al-sharîah. Baginya, penerapan istinbât manhajî sebagai metode perumusan hukum Islam memberi ruang yang luas bagi faqîh untuk mendalami permasalahan hukum yang sedang ia pecahkan berdasar pada sumber-sumber primer dengan memberi perbandingan dari sumber-sumber sekunder yang telah dirumuskan oleh imam-imam mazhab. Dengan pendekatan semacam ini, Zahro berpandangan fiqh akan terus hidup dan produknya akan dapat memenuhi kebutuhan masyarakat kontemporer terhadap ketetapan hukum Islam, misalnya pada permasalahan figh tentang hukum zakat profesi, hukum zakat dari bunga bank, 'iddah wanita karier, dan problematika fiqh lain yang belum diwariskan oleh imam-imam mazhab ketetapan fiqhnya.

\section{Daftar Rujukan}

al-Qardhawi, Yusuf. Kelunesan dan Keluasan Syariat Islam Menghadapi Perubaban Zaman, Terj. Tim Pustaka Firdaus. Jakarta: Pustaka Firdaus, 1996.

Bik, Muḥammad al-Khuḍârî. Târîkh al-Tashrî al-Islâmî. Beirut: Dâr alFikr, 1999.

${ }^{62}$ Ahmad Zahro, Wawancara, Sidoarjo, 10 Oktober 2014.

${ }^{63}$ Ibid. 
Haq, Abdul., Mubarok, Ahmad., Ro'uf, Agus. Formulasi Nalar Fiqh Telaah Kaidah Fiqh Konseptual. Surabaya: Khalista, 2006.

Hasan, M. Ali. Perbandingan Mað̧ab. Jakarta: Raja Grafindo Persada, 2003.

Hosen, Ibrahim. "Memecahkan Permasalahan Hukum Baru" dalam Haidar Bagir dan Syafiq Basri (eds.), Ijtibad dalam Sorotan. Bandung: Mizan, 1996.

Madjid, Nurcholis. "Tradisi Syarah dan Hasyiyah dalam Fiqh dan masalah Stagnasi Pemikiran Hukum Islam" dalam Budhy Munawar Rahman, Kontekstualisasi Doktrin Islam dalam Sejarah. Jakarta: Paramadina, 1995.

Maghfurin, Ahmad Lutfi. Tradisi Syarah dan Hasyiyah dalam Fikih: Stagnasi Hukum Islam. Surabaya: Makalah Pascasarjana, 2013.

Musawwir. "Potret Mazhab-mazhab Fiqh dalam Peradaban Islam", Istinbath, Vol. 3, Desember, 2005.

Muslehuddin, Muhammad. Filsafat Hukum Islam dan Pemikiran Orientalis Studi Perbandingan Sistem Hukum Islam, terj. Yudian Wahyudi Asmin et.al. Yogyakarta: Tiara Wacana, 1997.

Mustafa, Bisri. Tarjamah Nadam al-Farâid al-Bahîyah li Abî Bakar alAbdal. t.t: Menara Kudus, t.th.

Mahfudh, Sahal. Nuansa Figh Sosial. Yogyakarta: LKiS, 2003.

Saleh, Abdul Mun'im. Hukum Manusia sebagai Hukum Tuban: Berpikir Induktif Menemukan Hakikat Hukum Model al-Qawa'id al-Fiqhiyah. Yogyakarta: Pustaka Pelajar, 2009.

Shiddieqy, T.M. Hasbi Ash. Falsafah Hukum Islam. Jakarta: Bulan Bintang, 1990.

Yanggo, Huzaimah T. Pengantar Perbandingan Mazhab. Jakarta: Logos Wacana Ilmu, 1997.

Zahro, Ahmad. Figh Kontemporer Menjawab 111 Masalab + 33 Solusi Islami. Jombang: Unipdu Press, 2012.

-----. Tradisi Intelektual NU. Yogyakarta: LKiS, 2004

----. Wawancara. Sidoarjo, 10 Oktober 2014. 